\title{
KONTRIBUSI ISLAM TERHADAP PERADABAN BARAT
}

\author{
Ahmad Asmuni \\ IAIN Syekh Nurjati Cirebon (asmunistain@yahoo.com)
}

\begin{abstract}
Allah Almighty has created man as the most perfect being. Human perfection in the creation of its form, coupled with the giving of reason, then obviously human beings have a high level compared with other creatures. There are many graces of Allah SWT to human being, among them is the gift of reason. By the gift, people are able to think and to create and also to develop civilization. Islamic civilization reached the peak point and able to penetrate the mainland of Europe. The reality in turn has been a testament of how Islamic civilization has influenced Western civilization. The influence of Islamic civilization resulted the growth of new initiatives, creativity and productivity of higher quality that marked the existence of a model of civilization that is vibrant, dynamic, visionary and have a clear future orientation. And this is what in history is considered as an Islamic contribution to Western civilization.
\end{abstract}

Keywords: Islam, Civilization, Islamic Civilization, and Western Civilization

\begin{abstract}
Abstrak
Allah SWT telah menciptakan manusia sebagai makhluk yang paling sempurna. Kesempurnaan manusia dalam penciptaan bentuknya, ditambah dengan diberinya akal, maka jelas manusia memiliki tingkat yang tinggi dibandingkan dengan makhluk-makhluk lainnya Anugerah Allah SWT kepada manusia sangat banyak, di antaranya adalah anugerah akal. Dengan anugerah akal ini manusia mampu berpikir dan mampu menciptakan serta mengembangkan peradaban. Peradaban Islam pernah mencapai titik puncak sehingga mampu menembus daratan Eropa. Realitas tersebut pada gilirannya telah menjadi bukti betapa peradaban Islam telah mempengaruhi peradaban Barat. Pengaruh peradaban Islam mengakibatkan tumbuhnya berbagai inisiatif, kreativitas dan produktivitas baru yang lebih berkualitas yang menandai adanya model peradaban yang hidup, dinamis, visioner dan memiliki orientasi ke depan (future oriented) dengan jelas. Dan inilah yang dalam sejarah dianggap sebagai kontribusi Islam terhadap peradaban Barat.
\end{abstract}

Kata Kunci: Islam, Peradaban, Peradaban Islam, dan Peradaban Barat

\section{A. Pendahuluan}

Allah SWT, telah menciptakan manusia dengan memberinya anugerah akal. Dengan anugerah akal inilah manusia mampu mencapai puncak peradaban. Islam sebagai agama yang menghargai penggunaan akal tentu saja mendorong umat manusia untuk menggunakan akalnya demi kebahagiaan hidupnya baik di dunia maupun di akherat kelak.

Sejarah telah mencatat bahwa dengan kelebihan anugerah akal dari Allah SWT, manusia telah berada pada puncak kemajuan kebudayaan dan peradabannya. Kemajuan peradaban telah saling berkontribusi dan pengaruh mempengaruhi antar sesama manusia. Dalam hal ini, sejarah mencatat bahwa Islam telah berkontribusi terhadap peradaban Barat.

Dari perspektif peradaban, Islam mewujudkan nilai guna yang besar khususnya bagi manusia dengan mengadakan perubahan mendasar dari keadaan yang negatif-destruktif menjadi positif-konstruktif. Perubahan ini dilalui dengan memperbanyak kreasi-kreasi 
penelitian, keilmuan, penggalian, kepada makhluknya untuk berkreasi penemuan dan pengembangan. menciptakan peradaban itu. Jadi Kemudian Islam mengendalikan hasil kreasi-kreasi tersebut untuk diarahkan peradaban yang dibangun kaum Muslimin adalah peradaban yang pada keseimbangan antara prestasi, memotivasi dan menstimulir untuk lingkungan, martabat dan kedamaian, sehingga ilmu yang dikembangkan adalah keseimbangan antara science for science (ilmu untuk ilmu), science for society (ilmu untuk masyarakat) science for human dignity (ilmu untuk kemuliaan manusia), dan science for world peace (kedamaian dunia).

Dengan begitu, Islam adalah agama yang menjadi dasar peradaban, senantiasa memproduksi peradaban yang baru, menjadi pengendali peradaban, mengayomi peradaban dan akhirnya menjadi pengayom bagi alam semesta. ${ }^{1}$

Peradaban Islam merupakan peradaban yang bersandar pada konsep tauhid (mengesakan Allah) yang diwujudkan dalam tindakan riil dalam kehidupan masyarakat Muslim. Konsep tauhid ini memiliki konskuensi bahwa apapun yang diciptakan oleh para pakar Muslim setidaknya harus memiliki orientasi mentauhidkan Tuham, Allah Maha Agung, Allah Maha Kuasa dan Allah Maha Berilmu yang telah memberikan kekuat-an pengetahuan

\footnotetext{
${ }^{1}$ Muzamil Qomar, Merintis Kejayaan Islam Kedua Merombak Pemikiran dan Mengembangkan Aksi, Yogyakarta: Teras, 2012, hlm. 90.
} kepada Allah pencipta jagat raya ini dan pencipta kekuatan manusia yang menimbulkan seluruh peradaban yang pernah muncul di dunia ini.

Sesuai dengan sifat agama Islam yang universal dan internasional, peradaban Islam dimaksudkan untuk menjalankan misinya memberikan kemudahan-kemudahan hidup bagi seluruh umat manusia tanpa membedakan geografis, ras, etnik, agama, bangsa, dan negara dalam arti diskriminatif. Bahkan peradaban Islam sebaiknya dikonstruk untuk melindungi makhluk-makhluk lainnya selain manusia tentu dalam batas-batas tertentu untuk melestarikan dan memakmurkan alam semesta ini. Peradaban ini berasal dari Islam dan umatnya untuk seluruh makhluk Tuhan.

\section{B. Peradaban Islam}

\section{Makna Dasar Islam.}

Ada indikasi bahwa Islam adalah inisial seseorang masuk ke dalam lingkaran ajaran Ilahi. Sebuah Ayat Suci melukiskan bagaimana orang-orang 
Arab Badui mengakui telah beriman tapi Nabi diperintahkan untuk mengatakan kepada mereka bahwa mereka belumlah beriman melainkan baru ber-Islam, sebab iman belum masuk ke dalam hati mereka. $^{2}$ Jadi, iman lebih mendalam daripada Islam, ${ }^{3}$ sebab dalam konteks firman itu, kaum Arab Badui tersebut barulah tunduk kepada Nabi secara lahiriah, dan itulah makna kebahasaan perkataan "Islam", yaitu "tunduk" atau "menyerah".

Istilah "al-Islam" telah menjadi nama sebuah agama, khususnya agama yang dibawa oleh Nabi Muhammad SAW, yaitu agama Islam. Tapi, secara generik, "Islam" bukanlah nama dalam arti kata sebagai nama jenis atau sebuah proper noun. Dan ini melibatkan pengertian tentang istilah itu yang lebih mendalam, yang justru banyak ditemukan dalam Kitab Suci. Perkataan itu, sebagai kata benda verbal yang aktif, mengandung pengertian sikap pada sesuatu, dalam hal ini sikap pasrah atau menyerahkan diri kepada Tuhan. Dan sikap itulah yang disebutkan sebagai sikap keagamaan yang benar dan diterima Tuhan: "Sesungguhnya agama bagi Allah ialah sikap pasrah pada-Nya (al-Islam). ${ }^{4}$ Maka selain dapat diartikan sebagai nama sebuah agama, yaitu agama Islam, perkataan al-Islam dalam firman ini bisa diartikan secara lebih umum, yaitu menurut makna asalnya "pasrah kepada Tuhan". Inilah dasar pandangan dalam al-Qur'an bahwa semua agama yang benar adalah agama Islam, dalam pengertian semuanya mengajarkan sikap pasrah kepada Tuhan. ${ }^{5}$

Selanjutnya, penjelasan yang sangat penting tentang makna "al-Islam" ini juga diberikan oleh Ibn Taimiyah. Ia mengatakan bahwa "al-Islam mengandung dua makna, yaitu: pertama, ialah sikap tunduk dan patuh, jadi tidak sombong; kedua, ketulusan dalam sikap tunduk kepada satu pemilik atau penguasa, seperti difirmankan Allah, "wa rajulan salaman li rajulin" (Dan seorang lelaki yang tulus tunduk kepada satu orang lelaki). ${ }^{6}$

\footnotetext{
4 QS. Ali-Imran: 19

5 Abdurrahman Wahid, 'Universalisme Islam dan Kosmopolitanisme Islam', dalam Budhy Munawar Rachman (Ed), Kontekstualisasi Doktrin Islam Dalam Sejarah, Jakarta: Yayasan Wakaf Paramadina, 1994.

${ }^{6}$ QS. Al-Zumar: 29.
} 


\section{Pengertian Peradaban Islam}

Peradaban Islam adalah realitas yang terjadi dalam sejarah kehidupan manusia yang nilai-nilainya terkandung sumber ajaran Islam, yaitu Al-Quran dan Sunnah Nabi. ${ }^{7}$

Kata Peradaban Islam, ${ }^{8}$ adalah terjemahan dari kata Arab al-hadharah al-Islamiyyah. Kata Arab ini sering juga diterjemahkan ke dalam bahasa Indonesia dengan kebudayaan Islam. Kebudayaan dalam bahasa Arab adalah ats-tsaqafah. Di Indonesia, sebagaimana juga di Arab dan Barat, masih banyak orang yang menyinonimkan dua kata kebudayaan (Arab, ats-tsaqafah; Inggris, culture) dan peradaban (Arab, alhadhdrah; Inggris, civilization). ${ }^{9}$

Dalam perkembangan ilmu antropologi sekarang, istilah kebudayaan dan peradaban itu dibedakan yakni;

1. Kebudayaan adalah bentuk ungkapan tentang semangat mendalam suatu masyarakat, sedangkan manifestasimanifestasi kemajuan mekanis dan teknologis lebih berkaitan dengan peradaban. Kalau kebudayaan lebih banyak direfleksikan dalam seni, sastra, religi (agama), dan moral, peradaban terefleksi dalam politik, ekonomi, dan teknologi ${ }^{10}$

7 Rusydi Sulaiman, Pengantar Metodologi Studi Sejarah Peradaban Islam, op. cit., hlm. 101.

${ }^{8}$ Peradaban yang dimaksud dalam tulisan ini adalah Islam yang diwahyukan kepada Nabi Muhammad SAW, yang telah membawa bangsa Arab maju. Lihat Dedi Supriyadi, Sejarah Peradaban Islam, op. cit., hlm. 18.

9 Dedi Supriyadi. Sejarah Peradaban Islam., Ibid.

${ }^{10}$ Ibid.
2. Peradaban biasanya dipakai untuk bagian-bagian dan unsur-unsur dari kebudayaan yang halus dan indah. Menurutnya, peradaban sering juga dipakai untuk menyebut suatu kebudayaan yang mempunyai sistem teknologi, seni bangunan, seni rupa, sistem kenegaraan, dan ilmu pengetahuan yang maju dan kompleks.. ${ }^{11}$

Berdasarkan berbagai pengertian di atas, tampaknya para ahli sampai saat ini masih belum menemukan secara pasti perbedaan dalam memaknai arti keduanya (kebudayaan dan peradaban). Untuk memudahkan hubungan antara kebudayaan dan peradaban dalam studi ini, pendapat Oswald Speengler yang dikutip Samuel P. Huntington, dalam bukunya Dedi Supriyadi patut diperhatikan. Menurutnya, kebudayaan adalah untuk menunjuk upaya-upaya manusia yang masih terus berlanjut, sedangkan peradaban untuk menunjukkan titik akhir dari kegiatan mereka, tampaknya, sedikit banyak bisa membedakannya. Kebudayaan pada perspektif ini lebih dipandang sebagai bentuk respons masyarakat manusia dengan berbagai prosesnya yang bersifat teknis dan konseptual yang terus berkelanjutan terhadap persoalan di sekelilingnya. Sebaliknya, peradaban mengandung pengertian yang lebih luas sebagai makna puncak, spirit

${ }^{11}$ Ibid. 
keseluruhan, dan bersifat universal, sebagai karakter umum dari sebuah zaman dan titik akhir hasil dari berbagai hasil proses kebudayaannya. ${ }^{12}$

\section{Pembagian Peradaban}

Setiap bangsa di dunia ini memiliki peradaban masing-masing. Mereka mengunggulkan peradabannya itu sehingga berusaha menjunjung tinggi, mempertahankan atau bahkan mengembangkannya.

Problemanya adalah terletak pada kualitas, ada peradaban yang berkualitas tinggi sehingga mempengaruhi perkembangan dunia ini dan menjadi pusat perhatian seluruh penghuni bumi ini, sebaliknya terdapat peradaban yang kualitasnya rendah sehingga tidak terdengar dan tidak terpublikasikan dengan baik. Model peradaban yang kedua ini seringkali disebut tidak berperadaban.

Kualitas peradaban itu dipengaruhi oleh kecerdikan masyarakatnya. Ketika suatu masyarakat memiliki kadar intelektual, semangat, kreatiyitas, produktivitas dan idealisme yang tinggi maka peradaban yang dibangun tentu peradaban yang berkualitas tinggi juga. Oleh karena itu, negara yang berhasil

12 Tadjab dkk, Dimensi-Dimensi Studi Islam, Surabaya: Karya Aditama, 1994, hlm. 312. Lihat juga, Dedi Supriyadi, Sejarah Peradaban Islam, op., cit., hlm. 19. mengembangkan sains dan teknologi modern adalah negara yang masyarakatnya memiliki kriteria-kriteria tersebut seperti negara-negara Eropa dan Amerika belakangan ini. Bagi negara yang masyarakatnya tidak memiliki etos ilmiah tersebut, mereka terpaksa hanya sekadar menjadi konsumen setia.

Memang terdapat korelasi yang signifikan antara tingkat pendidikan yang melahirkan etos ilmiah tersebut dengan keberhasilan suatu negara mencapai kemajuan peradaban. Negaranegara yang menyandang gelar sebagai raja teknologi senantiasa berasal dari negara-negara yang masyarakatnya memiliki tingkat pendidikan yang relatif tinggi seperti Amerika, Jepang dan Inggris. Sementara negara yang kaya raya tidak selalu didukuhg oleh pendidikan yang tinggi, boleh jadi hanya anugerah dari Allah seperti Saudi Arabia yang menjadi kaya raya karena faktor pemberian Tuhan berupa sumber minyak yang terbesar di dunia dan keberadaan Ka'bah. $^{13}$

Melalui teori bahwa hampir setiap bangsa memiliki peradaban, maka jumlah peradaban di dunia ini banyak sekali dan sulit dideteksi. Hanya saja dapat dikelompokkan ke dalam rumpun

\footnotetext{
${ }^{13}$ Muzamil Qomar, Merintis Kejayaan Islam Kedua, hlm, 121.
} 
tertentu berdasarkan pada ciri-ciri umumnya. Abdul Aziz Othman Altwaijri mengamati peradaban dunia kemudian dan membaginya menjadi enam macam. Dia menegaskan bahwa jika mempertimbangkan dasar elemen budaya yang menentukan peradaban ada enam peradaban besar kontemporer yang dapat diidentifikasi yaitu peradaban Islam, peradaban Barat, peradaban India, peradaban Cina, peradaban Jepang dan peradaban Amerika Latin. ${ }^{30}$ Kemudian Abu Zaid berdasarkan kesimpulan satu dimensi saja, dia membaginya tiga: peradaban Mesir kuno adalah peradaban 'pasca kematian', peradaban Yunani adalah peradaban 'akal', sementara peradaban Arab Islam adalah peradaban 'teks'. ${ }^{31}$

\section{Ciri-Ciri Peradaban}

Masing-masing peradaban itu memiliki sesuatu yang ditonjolkan baik secara terprogram maupun secara kebetulan yang disebut ciri-ciri. Yudhoyono menjelaskan bahwa ciri peradaban Barat adalah kebebasan seperti demokrasi dan hak asasi manusia (human right), ciri perdaban Asia Timur adalah harmoni seperti kedamaian dan kerukunan sedangkan ciri peradaban Islam adalah keadilan (justice) seperti musyawarah dan persamaan derajat. ${ }^{33}$
Ciri-ciri atau karakteristik tersebut berfungsi untuk mengenali dan membedakan antara berbagai peradaban, tetapi bukan untuk mengadukannya, seperti teori Clash Civilization (benturan peradaban) yang dipublikasikan Samuel Huntington. Sesungguhnya peradaban tidak berbenturan kecuali oleh perilaku yag menyimpang dari pemilik maupun pengagum peradaban itu. Ada ungkapan yang relevan untuk menggambarkan posisi peradaban, yakni the man behind the gun. Peradaban ibarat the gun yang bersifat penurut, menuruti kehendak the man (orang penggunanya). Oleh karena itu, jika terjadi tindakan-tindakan radikal, yang bersalah bukanlah peradabannya melainkan orangorangnya.

Peradaban Barat, Asia Timur dan Islam, mestinya dapat disatukan karena masing-masing peradaban itu memiliki ciri-ciri yang sama-sama yaitu positif: kebebasan, harmoni dan keadilan. Ketiga ciri ini bisa diintegrasikan, satu sama lain saling membutuhkan. Kebebasan membutuhkan harmoni dan keadilan, harmoni membutuhkan kebebasan dan keadilan, dan keadilan juga membutuhkan kebebasan dan harmoni. Sebaiknya konsentrasi kita dipusatkan pada upaya penyatuan ketiga peradaban besar itu menjadi peradaban bersama. 


\section{Misi Dan Karakteristik \\ Peradaban Islam}

\section{a. Misi Peradaban Islam}

Peradaban Islam merupakan peradaban yang bersandar pada konsep tauhid (mengesakan Allah) yang diwujudkan dalam tindakan riil dalam kehidupan masyarakat Muslim. Konsep tauhid ini memiliki konsekuensi bahwa apapun yang diciptakan oleh para pakar Muslim setidaknya harus memiliki orientasi mentauhidkan Allah Maha Berilmu yang telah memberikan kekuatan pengetahuan kepada makhluknya untuk berkreasi menciptakan peradaban itu. Jadi peradaban yang dibangun kaum Muslimin adalah peradaban yang memotivasi dan menstimulir untuk meneguhkan kembali keimanan mereka kepada Allah.

Sesuai dengan sifat agama Islam yang universal dan internasional, peradaban Islam dimaksudkan untuk menjalankan misinya memberikan kemudahan-kemudahan hidup bagi seluruh umat manusia tanpa membedakan geografis, ras, etnik, agama, bangsa, dan negara. Bahkan peradaban Islam sebaiknya dikonstruk untuk melindungi makhluk-makhluk lainnya selain manusia tentu dalam batas-batas tertentu untuk melestarikan dan memakmurkan alam semesta ini.
Peradaban ini berasal dari Islam dan umatnya untuk seluruh makhluk Tuhan.

Dengan demikian, peradaban Islam di satu sisi harus senantiasa menghadirkan karya-karya keilmuan yang menjadi modal utama untuk mencapai kemajuaan sains dan teknologi, dan pada sisi lain harus bersikap ramah terhadap lingkungan baik lingkungan geografis, sosial maupun kultural. Ada keseimbangan antara ilmu dan kebajikan. Ilmu diperuntukkan bagi usaha mencapai kemajuan sedangkan kebajikan untuk meraih ketenangan dan kedamaian hidup manusia bersama dengan makhlukmakhluk lainnya. Dengan kata lain, peradaban bukan sekadar untuk mencapai prestasi kemajuan, melainkan juga untuk mencapai kesejahteraan universal.

Selain itu, peradaban Islampun harus menjadi penjaga gawang untuk dapat mempertimbangkan keseimbangan antara unsur materialistik dengan unsur spitritual. Tugas peradaban Islam mengkondisikan bagaimana kemajuankemajuan material yang dihasilkan atas kreativitas manusia Muslim itu selalu dipayungi oleh nilai-nilai spiritual. Dengan demikian, dimensi material dilapisi spiritual, sedangkan dimensi 
spiritual memotivasi pencapaian

material.

Akhirya, peradaban Islam menjadi peradaban yang stabil dan mampu bertahan sepanjang masa sehingga peradaban Islam bisa dinikmati oleh makhluk hidup yang digelar di muka bumi ini baik dahulu, sekarang dan masa yang akan datang. Peradaban Islam mengemban misi ajaran Islam sehingga menjadi peradaban yang "abadi". Peradaban Islam diusahakan untuk tetap bertahan sepanjang dunia ini ada. ${ }^{14}$

\section{b. Karakteristik Peradaban Islam}

Peradaban Islam memiliki karakter sendiri dan dalam beberapa hal berbeda dengan peradaban lainnya. Altwaijri menyimpulkan karakter tersebut menjadi lima macam:

1) Peradaban Islam merupakan peradaban yang didasari ke-imanan Islam, diilhami nilai-nilaainya dan prinsip-prinsipnya

2) Peradaban dengan kemanusiaan, berdimensi universal, dan tidak diasosiasikan pada wilayah greografis, bangsa dan era sejarah khusus.

3) Peradaban yang ramah yang memiliki adab-adab dan budaya-budaya kemanusiaan, yang dialami oleh orang-orang mulai zaman kuno dan banyak memberikan konstribusi pada kemajuan sains dan teknologi, pengetahuan dan nilai-nilai keadilan, kesamaan, keindahan dan kebajikan.

4) Peradaban seimbang yang menjamin keseimbangan dengan adil antara sisisisi materialistik dan spiritual dengan moderasi yang patut dicontoh yang selalu menjadi karakter pemikiran

14 Ibid, hlm. 125.
Islam dan keistimewaan khusus melalui sejarahnya.

5) Peradaban abadi yang akan survive sepanjang keberaaan Islam, sebab peradaban itu didasari ajaran Islam yang amat prinsip yang selalu dijamin Allah. ${ }^{15}$

Karakter-karakter tersebut di atas harus mewarnai peradaban Islam sehingga dibutuhkan kesatuan persepsi dan langkah dari umat Islam terutama para tokohnya baik ulama, syaikh, kiai, ustadz, guru, dosen, muballigh, pejabat Muslim, dermawan Muslim, politikus Muslim, dan seluruh orang Islam yang memegang kendali dalam jabatan dan profesi apapun. Hal ini dibutuhkan karena mengaktualisasikan karakteristik tersebut ke dalam perilaku umat Islam yang kemudian menjadi peradaban itu sangatlah berat. Apalagi jika peradaban Islam itu mencapai pencerahan. ${ }^{16}$

Bagi peradaban Islam, memang ada sejumlah harapan yang bisa diwujudkan dalam kehidupan intelektual, sosial, kultural dan religius sehari-hari. Harapan-harapan itu keadaannya menjadi aksi dalam kehidupan umat Islam sehingga benarbenar realistik, bukan sekadar sloganslogan atau pemikiran-pemikiran melangit yang kosong dari realitas. Peradaban Islam akan senantiasa diuji melalui bukti-bukti yang bisa

15 Ibid, hlm. 125.

16 Ibid, hlm. 126-127. 
diwujudkan, apakah bukti-bukti perbuatan umat Islam sesuai dengan janji-janji manis yang diucapkan, atau apakah seruan-seruan yang ada pada bibir umat Islam terutama tokohnya telah benar-benar teraktualisasikan dalam kehidupannya melalui gerakan tangan dan kaki?

\section{Simbol Peradaban Islam}

Setiap peradaban itu memiliki simbol yang merefleksikan makna tertentu. Adapun simbol peradaban Islam menurut Sayyed Hussein Nasr sebagaimana dikutip oleh Muzamil Qomar adalah "bukanlah sebuah sungai yang mengalir, tetapi sebuah kubus dari Ka'bah, stabilitas yang melambangkan karakter Islam yang permanen dan tidak berubah". Artinya stabilitas yang tetap dan terus terjaga dalam melakukan perubahan-perubahan yang makin baik dan makin sempurna. ${ }^{17}$

Selanjutnya, Islam, sebagai agama yang diturunkan kepada Nabi Muhammad lima belas abad yang lalu, berlaku pada semua ruang dan waktu, semua tempat dan zaman, dan semua lapisan masyarakat. Hal ini sebagai refleksi dari sifat pemberlakuannya yaitu permanen, universal dan internasional sehingga harus didakwahkan dimana

\footnotetext{
${ }^{17}$ Ibid, hlm. 1.
}

saja, kapan saja, dan dalam keadaan apapun. ${ }^{18}$

Oleh karena itu, dibutuhkaan pencerahan yang matang, pelaksanaan yang konsisten, dan evaluasi yang menyeluruh terhadap kerja dan aktivitas kaum Muslimin dengan segera menutup kelemahannya masing-masing dan membuka lembaran baru penuh strategi dan sinergi satu sama lainnya. Ini semua dilakukan untuk mewujudkan kemajuan peradaban Islam secara menyeluruh dan merata baik ilmu pengetahuan, teknologi, pendidikan, ekonomi, hukum, kesehatan, sosial dan sebagainya.

Disinilah perlunya menampilkan Islam sebagai sebuah peradaban. Karena dengan menampilkan Islam sebagai sebuah peradaban, maka kesan yang muncul adalah bahwa agama yang dibawa Nabi Muhammad ini dapat membumi bersahabat dengan masyarakat, memberikan serangkaian petunjuk kepada mereka, memberikan contoh-contoh dalam kehidupan riil dan sosial bagi mereka, memberikan pengayoman, sehingga mereka bisa diyakinkan bahwa Islam itu benar-benar agama yang rahmatan li al-'alamin (pengayom bagi alam semesta).Tampilan seperti ini tentu dipandang sebagai hal yang penting agar peradaban Islam tidak

18 Ibid, hlm. 2. 
hanya indah dalam lisan tapi juga indah dalam kenyataan.

\section{Peradaban Islam sebagai Warisan Sejarah}

Peradaban adalah kemajuan pengetahuan (scientific progress), sama halnya dengan kebangkitan scientific world view dalam jiwa individu dalam kehidupan sosial di tengah masyarakat. Dalam hal peradaban, fenomena mi disebut, "non-observable foundation" diartikan sebagai conceptual foundation adalah segala kerangka kerja mental sebagai analogi untuk menjelaskan perilaku manusia terhadap manusia lainnya di tengah masyarakat. ${ }^{19}$

Eksistensi peradaban selalu dikaitkan dengan konsep dasar peradaban, yaitu fenomena manusia yang berdasarkan kegiatan/ perilaku manusia. Perilaku tersebut muncul dalam dua bentuk, yaitu observable foundation dan non-observable foundation. ${ }^{20}$

Bukti bahwa kebudayaan Islam sebagai warisan sejarah diantaranya dapat dilihat dari banyaknya peninggalan buku-buku sejarah peradaban Islam baik yang ditulis dalam bahasa Inggris ataupun dalam bahasa Arab.

19 Rusydi Sulaiman, Pengantar Metodologi Studi Sejarah Peradaban Islam, op., cit., hlm. 107. ${ }^{20}$ Ibid.
7. Universalisme Islam dan
Kosmopolitanisne Islam

Universalisme Islam, ${ }^{21}$ menampakkan diri dalam berbagai manifestasi penting dan yang terbaik adalah dalam ajaran-ajarannya. Rangkaian ajaran yang meliputi berbagai bidang, seperti hukum agama (fiqh), keimanan (tauhid), etika (akhlaq, seringkali disempitkan oleh masyarakat hingga menjadi hanya kesusilaan belaka) dan sikap hidup, menampilkan kepedulian yang sangat besar kepada unsur-unsur utama dari kemanusiaan (alinsaniyyah). Prinsip-prinsip seperti persamaan derajat di muka hukum, perlindungan warga masyarakat dari kedzaliman dan kesewenang-wenangan, penjagaan hak-hak mereka yang lemah dan menderita kekurangan dan pembatasan atas wewenang para

21 Salah satu ajaran yang dengan sempurna menampilkan universalisme Islam adalah lima buah jaminan dasar yang diberikan agama samawi terakhir ini kepada warga masyarakat, baik seeara perorangan maupun sebagai kelompok. Kelima jaminan dasar itu tersebar dalam literatur hukum agama (al-kutub al-fiqhiyyah) lama, yaitu jaminan dasar akan (1) keselamatan fisik warga masyarakat dari tindakan badani di luar ketentuan liukum, (2) keselamatan keyakinan agama masing-masing, tanpa ada paksaan untuk berpindah agama, (3) keselamatan keluarga dan keturunan, (4) keselamatan harta benda dan milik pribadi di luar prosedur hukum, dan (5) keselamatan profesi. Lihat tulisan Abdurrahman Wahid, 'Universalisme Islam dan Kosmopolitanisme Islam', dalam Budhy Munawar Rachman (Ed), Kontekstualisasi Doktrin Islam Dalam Sejarah, Jakarta: Yayasan Wakaf Paramadina, 1994, hlm. 546. 
pemegang kekuasaan, semuanya jelas menunjukkan kepedulian di atas. ${ }^{22}$

Universalisme yang tercermin dalam ajaran-ajaran yang memiliki kepedulian kepada unsur-unsur utama kemanusiaan itu diimbangi pula oleh kearifan yang muncul dari keterbukaan peradaban Islam sendiri. Keterbukaan yang membuat kaum Muslim selama sekian abad menyerap segala macam menifestasi kultural dan wawasan keilmuan yang datang dari pihak peradaban-peradaban lain, baik yang yang masih ada waktu itu maupun yang sudah mengalami penyusutan luar biasa (seperti peradaban Persia). Kearifan yang muncul dari proses saling pengaruh-mempengaruhi antara peradaban-peradaban yang dikenal di kawasan "Dunia Islam" pada waktu itu, yang kemudian mengangkat peradaban Islam ke tingkat sangat tinggi, hingga menjadi apa yang disebutkan sejarawan agung Arnold J. Toynbee sebagai oikumene (peradilan dunia) Islam. Oikumene Islam ini, menurut Toynbee, adalah salah satu di antara enam belas oikumene yang menguasai dunia. Kearifan dari oikumene Islam itulah yang paling tepat untuk disebut sebagai kosmopolitanisme peradaban Islam. ${ }^{23}$

${ }^{22} \mathrm{Ibid}, \mathrm{hlm} .545$

${ }^{23} \mathrm{Ibid}, \mathrm{hlm}$. 545-546.
Kosmopolitanisme

peradaban Islam itu muncul dalam sejumlah unsur dominan, seperti hilangnya batasan etnis, kuatnya pluralitas budaya dan heterogenitas politik. Kosmopolitanisme itu bahkan menampakkan diri dalam unsur dominan yang menakjubkan, yaitu kehidupan beragama yang eklektik selama berabad-abad. Kalau ditelusuri dengan cermat perdebatan sengit di bidang teologi dan hukum agama selama empat abad pertama sejarah Islam, akan tampak secara jelas betapa beragamnya pandangan yang dianut oleh kaum Muslim waktu itu. Kalaupun hal itu dianggap sebagai kemelut kehidupan beragama kaum Muslim, karena tidak adanya konsensus atas hal-hal dasar, maka harus juga dibaca dengan cara lain bahwa pemikir Muslim telah berhasil mengembangkan watak kosmopolitan dalam pandangan budaya dan keilmuan mereka, karena mampu saling berdialog secara demikian bebas. Kebebasan kaum Mu'tazilah untuk mempertanyakan kebenaran ajaran sentral bahwa alQur'an turun dalam bentuk huruf dan bahasa yang sekarang dikenal (bahasa Arab, huruf Hija'iyyah) dan menganggap Kitab Suci kaum Muslim tersebut diturunkan hanya secara maknawi belaka, sesuatu yang sekarang tentunya dianggap sikap seorang murtad dari 
agama Islam, adalah dari pertanda kuatnya watak kosmopolitan dari peradaban Islam pada waktu itu. ${ }^{24}$

Pada wujud real, arsitektur Islam itu sendiri, secara keseluruhan-nya, mencerminkan watak kosmopolit budaya Islam. Arsitektur sebagai perwujudan seni-budaya Islam digambarkan oleh Sir Thomas W. Arnold yang dikutip oleh Nurcholish Madjid sebagai berikut:

\begin{abstract}
Muhammadan art may well claim a place among the greatest achievements of man's artistic activity. Its supreme expression is in architecture, in which the followers of Islam or the architect they employed worked out a scheme of building construction and of decoration in harmony with the austerity and dignity of their faith and adapted to its ritual and forms of worship. The great courtyard of the mosque of Ibn Tulun in Cairo, or Akbar's mosque in Fathur-Sikri; the massive structure of the mosque Hasan in Cairo, the great mosque of Qayrwan, the mosque of Imam Riza in Mashad, are among the noblest houses of worship in the world; and the mosque of Cordova, the Sulaymaniyyah mosque in Constantinople, the Dome of the Rock in Jerusalem, are unsurpassed for richness of color decoratioan. ${ }^{25}$
\end{abstract}

Terkait dengan Kebudayaan Islam, Nurcholish Madjid menjelaskan, cakupan budaya Islam, sebagai budaya universal dan kosmopolit, luas sekali, yang bagaimana pun tak mungkin dibicarakan seluruhnya. Maka yang diharap ialah bahwa sedikit yang telah

${ }^{24}$ Ibid, hlm. 549.

25 Nurcholish Madjid, 'Universalisme Islam dan Kosmopolitanisme Islam', dalam Islam Doktrin dan Peradaban; Sebuah Telaah Kritis Tentang Masalah Keimanan, Kemanusiaan, dan Kemodernan, Jakarta: Yayasan Wakaf Paramadina, 1995, hlm.,445. dikemukakan di atas memberi kita gambaran tentang budaya Islam itu. Kesemuanya itu kembali kepada pokok pembahasan kita, yaitu bahwa konsep alIslam yang universal melandasi sebuah agama dengan impulse universalisme yang amat kuat, dan melahirkan budaya dengan watak kosmopolit. ${ }^{26}$

Dengan demikian dapat disimpulkan, bahwa kosmopolitanisme peradaban Islam tercapai atau berada pada titik optimal, manakala tercapai keseimbangan antara kecenderungan normatif kaum Muslim dan kebebasan berfikir semua warga masyarakat (termasuk mereka yang non-Muslim). Kosmopolitanisme seperti itu adalah kosmopolitanisme yang kreatif, karena di dalamnya warga masyarakat mengambil inisiatif untuk mencari wawasan terjauh dari keharusan berpegang pada kebenaran. Situasi kreatif yang memungkinkan pencarian sisi-sisi paling tidak masuk akal dari kebenaran yang ingin dicari dan ditemukan, situasi cair yang memaksa universalisme ajaran Islam untuk terusmenerus mewujudkan diri dalam bentukbentuk nyata, bukannya nyata dalam postulat-postulat spekulatif belaka.

${ }^{26}$ Ibid. 


\section{Islam dan Peradaban Barat}

1. Hubungan Makna Kebudayaan dan Peradaban.

Istilah Peradaban Islam adalah terjemahan dari kata "Arab al-hadharah al-Islamiyyah. Kata Arab ini sering juga diterjemahkan ke dalam bahasa Indonesia dengan kebudayaan Islam. Kebudayaan dalam bahasa Arab adalah ats-tsaqafah. Di Indonesia, sebagaimana juga di Arab dan Barat, masih banyak orang yang menyinonimkan dua kata kebudayaan (Arab, ats-tsaqafah; Inggris, culture) dan peradaban (Arab, alhadhdrah; Inggris, civilization). Dalam perkembangan ilmu antropologi sekarang, kedua istilah itu dibedakan. Kebudayaan adalah bentuk ungkapan tentang semangat mendalam suatu masyarakat, sedangkan manifestasimanifestasi kemajuan mekanis dan teknologis lebih berkaitan dengan peradaban. $^{27}$

Adapun istilah peradaban biasanya dipakai untuk bagian-bagian dan unsurunsur dari kebudayaan yang halus dan indah. Menurutnya, peradaban sering juga dipakai untuk menyebut suatu kebudayaan yang mempunyai sistem teknologi, seni bangunan, seni rupa, sistem kenegaraan, dan ilmu

${ }^{27}$ Dedi Supriyadi, Sejarah Peradaban Islam, op., cit., hlm. 18. pengetahuan yang maju dan kompleks. Jadi, kebudayaan menurut definisi pertama adalah wujud ideal dalam definisi Koentjaraningrat, sementara menurut definisi terakhir, kebudayaan mencakup juga peradaban, tetapi tidak sebaliknya. Dalam pengertian itulah, peradaban yang dimaksud dalam buku ini. Islam yang diwahyukan kepada Nabi Muhammad SAW. telah membawa bangsa Arab yang semula terbelakang, bodoh, tidak terkenal, dan diabaikan oleh bangsa-bangsa lain, menjadi bangsa yang maju. la dengan cepat bergerak mengembangkan dunia, membina satu kebudayaan dan peradaban yang sangat penting artinya dalam sejarah manusia hingga sekarang. Bahkan, kemajuan Barat pada mulanya bersumber dari peradaban Islam yang masuk ke Eropa melalui Spanyol. Islam memang berbeda dari agama-agama lain. H.A.R. Gibb di dalam bukunya Whither Islam sebagaimana dikutip oleh Dedi Supriyadi, "Islam is indeed much more than a system of theology, it is a complete civilization".

(Islam sesungguhnya lebih dari sekadar sebuah agama, ia adalah suatu peradaban yang sempurna). Karena yang menjadi pokok kekuatan dan sebab timbulnya kebudayaan adalah agama Islam, kebudayaan yang ditimbulkannya 
dinamakan kebudayaan atau peradaban Islam. $^{28}$

\section{Kontribusi Islam Terhadap Peradaban Barat.}

Perjumpaan Islam dengan Yunani mendorong para filosof Muslim untuk mempelajari karya-karya filosof Yunani, menerjemahkannya, dan kemudian mengembangkannya sehingga turut memberikan sumbangan pada kemajuan peradaban Islam. Namun, Islam memiliki jasa yang besar karena Islamlah yang menyelamatkan peradaban Yunani yang pada awal Islam hampir tenggelam, dan menginternasionalisasikannya sehingga dikenal di seantero dunia. ${ }^{29}$

Setelah perjumpaan dengan Yunani, seiring dengan ekspansi Islam ke Spanyol, perjumpaan dilanjutkan Islam dengan Barat. Perjumpaan itu melalui kontak politik, kontak militer, kontak sosial dan kontak ilmiah atau kontak keilmuan yang terjadi secara

28 Ibid.

29 Dalam konteks peradaban Islam ini, Yunani sengaja dibedakan dengan Barat meskipun secara geografis wilayah Yunani berada di kawasan Barat. Sebab keduanya memiliki sejarah yang berbeda bahkan bertolak belakang dalam kaitan-nya dengan Islam. Dari segi waktu, kejayaan Yunani terjadi sebelum keberadaan peradaban Islam sedang kejayaan Barat terjadi setelah kejatuhan Islam. Sedangkan dari segi interaksi, peradaban Yunani mempengaruhi peradaban Islam sedang peradaban Islam justru mempengaruhi peradaban Barat. Lihat, Muzamil Qomar, Merintis Kejayaan Islam Kedua, op., cit., hlm. 36. langsung dan vis to vis terutama saat berada di bawah kekuasaan dinasti Umayyah yang berada di Spanyol. Melalui Spanyol ini, Islam memancarkan cahaya pencerahan di Barat

Gerakan filosofis dalam Islam yang menghasilkan khazanah paling kaya dari budaya intelektual Islam serta mempengaruhi pemikiran Barat begitu dalam dan berlangsung lama, adalah kontinuitas pengalaman-pengalaman berpikir rasional Mu'tazilah selama abad-abad kedua, ketiga dan keempat. ${ }^{68}$

Mu'tazilah memang dikenal sebagai aliran teologi yang paling rasional dalam Islam, yang memiliki kerangka berpikir ke depan. Aliran ini memiliki semangat yang kuat untuk memberdayakan akal baik dalam memahami ajaran-ajaran agama maupun dalam mencapai kemajuan.

Pola pikir Mu'tazilah yang mengapresiasikan akal itu pada perkembangan berikutnya setelah kemunduran Islam tidak lagi dijadikan pola di kalangan umat Islam, sebaliknya, pola pikir itu sangat direspons dan dikembangkan oleh Barat sehingga kawasan Barat dapat mencapai kemajuan yang luar biasa terutama di bidang pengetahuan.

Para filosof dan ilmuan Muslim memiliki andil besar di dalam 
melakukaan transmisi keilmuan itu dari dunia Islam ke dunia Barat. A. Qodri Azizy sebagaimana dikutip oleh Muzamil Qomar menegaskan bahwa dari segi pemikiran, renaissance yang merupakan cikal bakal kemajuan Barat tidak bisa lepas dari pengaruh dan sumbangan pemikiran para sarjana Muslim di abad sebelumnya. Ketika Barat masih menyandang gelar dark ages (abad kegelapan), dunia Muslim sudah memiliki peradaban yang maju dan sudah memperkenalkan metode induktif dan beberapa metode yang menjadi embrio kemajuan masa berikutnya di Barat. ${ }^{30}$

Islam telah menempuh perjalanan yang panjang ke arah Barat hingga ke Maroko yang terkenal dengan daerah Maghriby, dan Spanyol dalam waktu yang lebih dari dua abad. Perjalanan tersebut mengakibatkan terjadinya interaksi antara Islam dengan Barat makin intens sekali, baik interaksi sosial, interaksi kultural dan interaksi intelektual antara keduanya, sehingga terjadi titik pertemuan antara peradaban Islam yang dibawa orang-orang Arab dan peradaban Barat yang dimiliki Spanyol khususnya, sebuah pertemuan dua macam peradaban dengan corak yang berlawanan yaitu peradaban Islam

\footnotetext{
${ }^{30}$ Ibid., hlm. 36.
}

yang maju dan peradaban Barat yang terbelakang saat itu. Sebagai peradaban yang telah maju, banyak menumbuhkaan kreasi-kreasi baru baik bercorak kultural maupun intelektual. Kreasi kultural diwujudkan dalam bentuk peningkatan semangat dan etos kerja, kedisiplinan dan pemanfaatan waktu. Sedangkan kreasi intelektual diwujudkan dalam bentuk upaya-upaya perenungan untuk mengungkapkan konsep-konsep teoritis aplikatif.

Maurice Bucaille sebagaimana dikutip oleh Muzamil Qomar menuturkan sebagai berikut:

"Di Cordoba (Qurtubah) perpustakaan khalifah memuat 400.000 buku, Ibn Rusyd mengajar di situ. Banyak orang dari berbagai daerah di Eropa datang ke Qurtubah untuk belajar seperti pada waktu ini banyak orang belajar ke Amerika Serikat. Banyak manuskriprnanuskrip lama sampai kepada kita dengan perantaraan orang-orang dan membawa kebudayaan kepada negerinegeri yang ditaklukkan. Banyak hutang kami (orang-orang Barat) kepada pengetahuan Arab dalam matematika (kata al-Jabar adalah kata Arab), astronomi, fisika dan optik, geologi, ilmu tumbuh-tumbuhan (botanik), ilmu kedokteran (Ibnu Sina) dan lain-lain. Untuk pertarna kali sains mempunyai sifat internasional dalam universitas Islam pada abad pertengahan., 31

Muzamil Qomar menjelaskan bahwa "Para filosof dan ilmuan Muslim ibarat guru sedangkan para filosof dan ilmuan Barat ibarat murid. Mereka (para filosof dan ilmuan Muslim) menjalankan 
tugasnya sebagai guru dalam membangun kepribadian murid, antara lain; memberikan bimbingan kepada murid-murid yang belum mengerti, memberikan petunjuk bagi mereka yang tersesat, memberikan pelatihan bagi mereka yang belum terampil, memberikan pemahaman bagi mereka yang belum paham, memberikan penjelasan bagi mereka yang belum jelas, dan memberi pengetahuan mengenai orientasi yang dituju.

Lebih lanjut Muzamil Qomar Sebagai guru yang baik, para filosof dan ilmuan justru bersikap sangat terbuka kepada siapapun, bersikap adil kepada siapapun termasuk kepada orang-orang Barat yang berbeda agama sekalipun, menyelamatkan mereka yang terancam dari bahaya kehancuran. Semua tindakan ini dilakukan untuk kemajuan muridnya, yakni dunia Barat yang pada waktu itu masih tertinggal bahkan terbelakang, di samping tentu juga untuk mempertahankan integritas kepribadian guru, yakni para filosof dan ilmuan Muslim tersebut agar tetap berkembang dan terus berkreasi.

Dari sini tampak betapa besarnya pengaruh peradaban Islam pada dunia Barat melalui perjumpaan dan pergumulan yang intent sekali dengan literatur-literatur hasil karya sarjana
Islam. Melalui literatur-literatur ini, pikiran mereka terpengaruhi, kemudian mereka mengikuti dan mengalokasikan dalam pembahasan-pembahasan ilmiah mereka, bahkan mereka berusaha mempertahankan hingga sekarang ini.

Itulah gambaran sepintas konstribusi Islam terhadap perdaban Barat modern. Islam telah membukakan jalan bagi dunia Barat melalui berbagai kreasi yang diciptakan, berbagai percobaan yang diupayakan, berbagai temuan yang digali, dan berbagai teori yang dirumuskan. Ini semua mengilhami dan mempengaruhi para sarjana Barat, sehingga mereka berupaya meniru dan melanjutkan prestasi peradaban Islam tersebut hingga sekarang.

Pada masa klasik umat Islam telah mengukir prestasi yang gemilang. Mereka telah berhasil mencapai kejayaan di berbagai bidang peradaban. Kejayaan itu memantulkan sinarnya ke seantero dunia yang berasal dari Timur dan Barat. Poros Timur berpusat di Baghdad sedangkan poros Barat berpusat di Cordova Spanyol. Kedua poros itu meskipun berasal dari dua dinasti yang berseteru yaitu Abbasiyyah di Timur dan Umayyah di Barat, namun keduanya memiliki komitmen yang tinggi untuk memajukan peradaban Islam. 
Pada saat itu umat Islam menjadi penguasa dunia, sementara negeri-negeri yang telah maju seperti Romawi sedang mengalami kemunduran karena didera kekalahan perang sedangkan negerinegeri lainnya masih tertinggal. Keberhasilan menjadi penguasa dunia itu sebagai hasil dari perjuangan panjang mulai dari Nabi sebagai peletak dasar peradaban Islam pertama. Nabi merintis jalan paling awal untuk dilalui peradaban, kemudian para sahabat, tabi'in dan tabi'at melanjutkannya. Mereka tinggal melanjutkan bangunan yang telah dirancang oleh Nabi.

Memang membicarakan peradaban Islam, tentu saja tidak bisa dilepaskan dari Islam periode Nabi Muhammad SAW, di Semenanjung Arab pada permulaan abad ke-7 M, bagaimana situasi Arab sebelum kemunculan Islam, Nabi sebagai kepala agama di Mekkah, dan pembinaan masyarakat hingga pembentukan Negara Madinah pertama, serta penyatuan penduduk Jazirah Arab dalam mengembangkan agama Islam.

Setelah itu, proses ekspansi besarbesaran dilakukan, sehingga kawasan Islam pun meluas ke beberapa wilayah di sekitarnya: Persia dan Asia Tengah, Afrika Utara dan Pantai Atlantik, kawasan pusat-pusat peradaban lama, Spanyol sampai ke pegunungan Pyrenia, dari Tunisia ke Sisilia di Italia Selatan. Wilayah Balkan, Kaukasus dan Eropa Tengah atau apa yang terkenal sekarang dengan Rusia Selatan juga tak ketinggalan mendapat sentuhan kekuasaan Islam. Cukup luas wilayah kekuasaan dan pengaruh Islam di dunia, karena juga sampai ke India, Cina dan bahkan Asia Tenggara dan Indonesia. . ${ }^{32}$

Tak ketinggalan pula di Eropa, kekuasaan Islam tidak hanya terbatas di Barat. Di Eropa Timur terdapat beberapa wilayah yang pernah ditaklukkan dan berada di bawah pengaruh kekuasaan Islam, puncak kejayaan Islam atas Eropa ketika berkuasanya Sulaiman al-Qanuni (al-Fatih), penguasa Turki Utsmani dengan ibukota Konstantinopel pada tahun 1453. Setelah itu Islam meluas ke Yunani, Balkan, Hongaria dan Polandia. ${ }^{33}$ Dari titik inilah Barat banyak belajar dari Islam dan dari titik ini pula Islam sesungguhnya memiliki kontribusi yang besar terhadap peradaban Barat.

\section{Penutup}

Islam sebagai agama yang mendorong umatnya kepada kebudayaan dengan menempatkan akal pada posisi yang istimewa, maka pada gilirannya

\footnotetext{
32 Rusydi Sulaiman, Pengantar Metodologi Studi Sejarah Peradaban Islam, op., cit., hlm. 108.

${ }^{33}$ Ibid.
} 
menempatkan ummatnya - yang menggunakan akalnya dengan baik berada pada posisi sebagai umat yang memiliki peradaban yang sangat maju. Bahkan berdasarkan fakta sejarah dapat diketahui bahwa umat Islam pernah mencapai puncak peradaban dan peradabannya telah mempengaruhi umat-umat lain di dunia Barat. Hal ini jelas menunjukkan adanya kontribusi Islam dan umat Islam terhadap dunia Barat.

\section{Daftar Pustaka}

Wahid,

Abdurrahman.

1994. 'Universalisme Islam dan Kosmopolitanisme Islam', dalam Budhy Munawar Rachman (Ed). Kontekstualisasi Doktrin Islam Dalam Sejarah. Jakarta: Yayasan Wakaf Paramadina.
Rachman, Budhy Munawar (Ed). 1994. Kontekstualisasi Doktrin Islam Dalam Sejarah. Jakarta: Yayasan Wakaf Paramadina.

Supriyadi, Dedi. 2008. Sejarah Peradaban Islam. Bandung: Pustaka Setia.

Qomar, Muzamil. 2012. Merintis Kejayaan Islam Kedua. Merombak Pemikiran dan Mengembangkan Aksi. Yogyakarta: Teras.

Madjid, Nurcholish. 1995. 'Universalisme Islam dan Kosmopolitanisme Islam', dalam Islam Doktrin dan Peradaban; Sebuah Telaah Kritis Tentang Masalah Keimanan, Kemanusiaan, dan Kemodernan. Jakarta: Yayasan Wakaf Paramadina.

Sulaiman, Rusydi. 2014. Pengantar Metodologi Studi Sejarah Peradaban Islam. Jakarta: PT Persada Raja Grapindo Persada.

Tadjab, dkk. 1994. Dimensi-Dimensi Studi Islam. Surabaya: Karya Aditama. 